\title{
RANCANG BANGUN SISTEM INFORMASI PENJUALAN, PEMBELIAN DAN PERSEDIAAN SUKU CADANG PADA BENGKEL TIGA PUTRA MOTOR GARUT
}

\author{
Hanhan Hanafiah Solihin ${ }^{1)}$, Arvid Alnuron Fuja Nusa ${ }^{2)}$ \\ Program Studi Sistem Informasi \\ Universitas Sangga Buana YPKP Bandung \\ hanhan.hanafiah@usbypkp.ac.id ${ }^{1)}$, arvidalnuronfujanusa@ rocketmail.com ${ }^{2)}$
}

\begin{abstract}
ABSTRAK
Perusahaan Bengkel Tiga Putra Motor Garut merupakan perusahaan yang bergerak di bidang usaha otomotif yang melayani penjualan suku cadang dan pelayanan jasa servis. Dalam proses bisnisnya, pencatatan data transaksi penjualan membutuhkan waktu yang cukup lama karena data ditulis secara konvensional. Untuk dapat mengatasi permasalahan yang terjadi pada Perusahaan Bengkel Tiga Putra Motor dibuatlah perancangan dan pembangunan aplikasi Sistem Informasi penjualan, pembelian dan persediaan suku cadang berbasis website. Metode yang digunakan untuk pembangunan sistem informasi menggunakan Model Waterfall dengan dimodelkan menggunakan Flow Map, Context Diagram dan Data Flow Diagram (DFD). Hasil akhir dari perancangan dan pembangunan aplikasi sistem informasi ini adalah adanya sebuah aplikasi yang dapat memberi kemudahan transaksi penjualan, pembelian, dan persediaan suku cadang pada Bengkel Tiga Putra Motor Garut sehingga proses transaksi menjadi lebih efektif dan efisisen.
\end{abstract}

Kata Kunci : sistem informasi, penjualan, pembelian, persediaan, website

\section{PENDAHULUAN}

Penggunaan teknologi dapat menunjang dan meningkatkan keberhasilan aktivitas bisnis, sehingga banyak perusahaan berlombalomba menerapkan teknologi untuk bersaing dengan perusahaan lain. Dengan perkembangan teknologi yang semakin cepat, membuat perusahaan juga harus mengikuti perkembangan teknologi yang ada dan ingin menjadi yang terbaik dari perusahaan lain.

Bengkel Tiga Putra Motor yang berada di kampung Cilongkrang, Kecamatan. Karangpawitan Garut merupakan perusahaan yang bergerak di bidang usaha otomotif yang melayani penjualan suku cadang untuk berbagai merek dan pelayanan jasa servis. Suku cadang yang terdapat di Bengkel Tiga Putra Motor cukup banyak dan komplit untuk berbagai sepeda motor dari mulai suku cadang mesin, cover body motor, variasi motor dan lain-lain.

Namun dalam proses bisnisnya, Bengkel Tiga Putra Motor belum menggunakan teknologi informasi, sehingga terdapat beberapa kendala yang ditemukan dalam proses bisnisnya, pencatatan data transaksi penjualan membutuhkan waktu yang cukup lama karena data ditulis secara manual sehingga banyak data yang masih tercecer. Dalam penginputan data penjualannya pun seringkali terdapat kesalahan sehingga data penjualan suku cadang tidak lagi akurat. Kemudian untuk pengecekan, update dan pencarian stok suku cadang membutuhkan waktu yang lama, karena tidak adanya laporan stok suku cadang yang akan segera habis atau sudah habis., sehingga apabila terdapat konsumen yang membutuhkan suku cadang sering kali konsumen menunggu cukup lama karena perusahaan mengecek secara manual dengan cara mengecek langsung ke gudang.

Dengan demikian kebutuhan akan suatu konsep dan mekanisme pengelolaan proses penjualan, pembelian dan persediaan suku cadang dengan memanfaatkan teknologi informasi menjadi hal yang perlu dipertimbangkan.

Sehingga masalah yang terjadi dapat diidentifikasikan sebagai berikut : 
1. Terjadinya keterlambatan dalam pelayanan penjualan suku cadang motor. Karena pencarian stok barang berupa lembaran dokumen yang menggunakan waktu yang cukup lama .

2. Masih terjadi kesulitan dalam pengontrolan stok suku cadang yang masuk ataupun keluar, karena sistem yang berjalan masih secara manual.

3. Adanya keterlambatan dalam pembuatan laporan stok barang yang ada di gudang dan data penjualan kepada pemilik perusahaan. Di karenakan pengolahan laporan data masih menggunakan pencatatan manual.

Dari masalah yang telah diidentifikasikan, tujuan yang ingin dicapai pada penelitian ini adalah :

1. Mengetahui sistem penjualan, pembelian dan persediaan suku cadang sepeda motor berbasis web di Bengkel Tiga Putra Motor.

2. Membuat perancangan sistem informasi penjualan, pembelian dan persediaan suku cadang sepeda motor berbasis web yang sesuai untuk diterapkan di Bengkel Tiga Putra Motor.

3. Membangun Aplikasi Sistem Informasi Penjualan, Pembelian dan Persediaan Suku Cadang sesuai dengan rancangan yang telah dibuat.

Agar penelitian ini lebih terarah dan memudahkan dalam pembahasan, maka perlu adanya batasan permasalahan yang dibahas dalam pembuatan sistem informasi, adapun batasan masalah adalah sebagai berikut:

1. Sistem ini hanya mencakup penjualan, pembelian dan persediaan suku cadang

2. Penelitian ini tidak membahas retur produk penjualan dan pembelian suku cadang.

3. Penelitian ini tidak membahas sistem informasi pelayanan jasa servis.

\subsection{Landasan Teori}

\section{Pengertian Sistem}

Lucas mendefinisikan, "Sistem sebagai suatu komponen atau variabel yang terorganisir, saling berinteraksi, saling bergantung satu samalain dan terpadu". [1]

\section{Pengertian Informasi}

"Informasi adalah Data yang diolah menjadi bentuk yang lebih berguna dan lebih berarti bagi yang menerimanya". [2]

\section{Pengertian Sistem Informasi}

Pengertian sistem informasi menurut Robert A. Leitch \& K. Roscoe Davis, "Sistem informasi adalah suatu sistem didalam suatu organisasi yang mempertemukan kebutuhan pengolahan transaksi harian, mendukung operasi bersifat manajerial dan kegiatan strategi-strategi dari suatu organisasi dan menyediakan pihak luar tertentu dengan laporan-laporan yang diperlukan". [2]

\section{Pengertian Perancangan}

"Perancangan adalah suatu kegiatan yang memiliki tujuan untuk mendesign sistem baru yang dapat menyelesaikan masalah-masalah yang dihadapi perusahaan yang diperoleh dari pemilihan alternatif sistem yang terbaik". [1]

\section{Pengertian Penjualan}

"Merupakan sebuah proses dimana kebutuhan pembeli dan kebutuhan penjualan dipenuhi, melalui antar pertukaran informasi dan kepentingan". [3]

\section{Pengertian Pembelian}

Pembelian adalah sebagai salah satu fungsi dari pembelanjaan atau merupakan kegiatan dari pembelanjaan. Pembelian sama pentingnya dengan penjualan, yaitu untuk memenuhi kebutuhan setiap perusahaan, seperti kebutuhan peralatan kantor, gedung, peralatan produksi, dan lain sebagainya. [4]

\section{Pengertian Persediaan}

"Persediaan merupakan aktiva lancar yang ada dalam suatu perusahaan, apabila perusahaan tersebut perusahaan dagang maka persediaan diartikan sebagai barang yang disimpan untuk dijual dalam operasi normal perusahaan, sedangkan apabila perusahaan merupakan perusahaan manufaktur maka persediaan diartikan sebagai bahan baku yang terdapat dalam proses produksi atau yang disimpan untuk tujuan proses produksi” [5] 


\subsection{Metode Penelitian}

Untuk metode pengembangan sistem dalam membangun perangkat lunak sistem informasi ini menggunakan metode Waterfall, yaitu model yang menggambarkan tahapan pengembangan sistem secara sistematik dan berurut.

Berikut gambar pengembangan perangkat lunak Metode Waterfall dapat dilihat pada gambar 1.

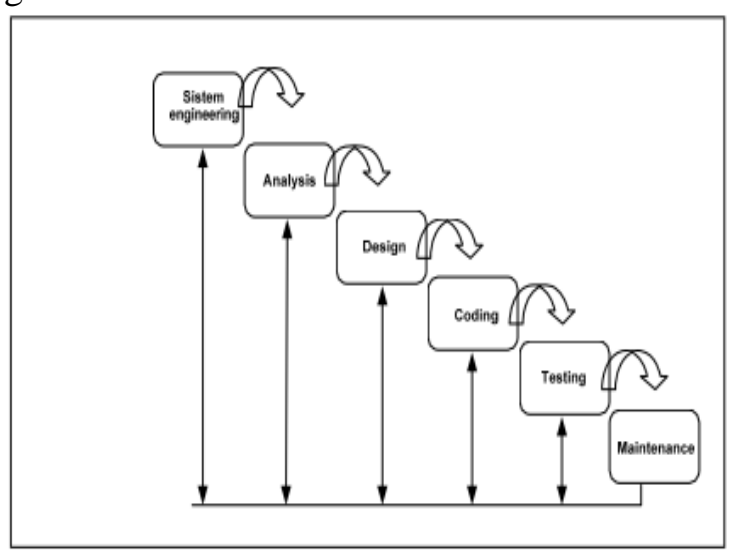

Gambar 1. Pengembangan Perangkat Lunak Metode Waterfall. [6]

\section{PEMBAHASAN}

\subsection{Analisis Prosedur yang Sedang Berjalan}

Analisis sistem dapat didefinisikan sebagai penguraian dari suatu sistem informasi yang utuh ke dalam bagian-bagian komponen dengan maksud untuk mengidentifikasikan dan mengevaluasi permasalahan, kesempatan dan hambatan yang terjadi dalam kebutuhankebutuhan yang diharapkan, sehingga dapat di usulkan perbaikan sistem. Berikut adalah Flow Map, Context Diagram dan DFD Penjulan, Pembelian dan Persediaan Suku Cadang yang sedang berjalan di Bengkel Tiga Putra Motor dapat dilihat pada Gambar 2 sampai dengan 7.

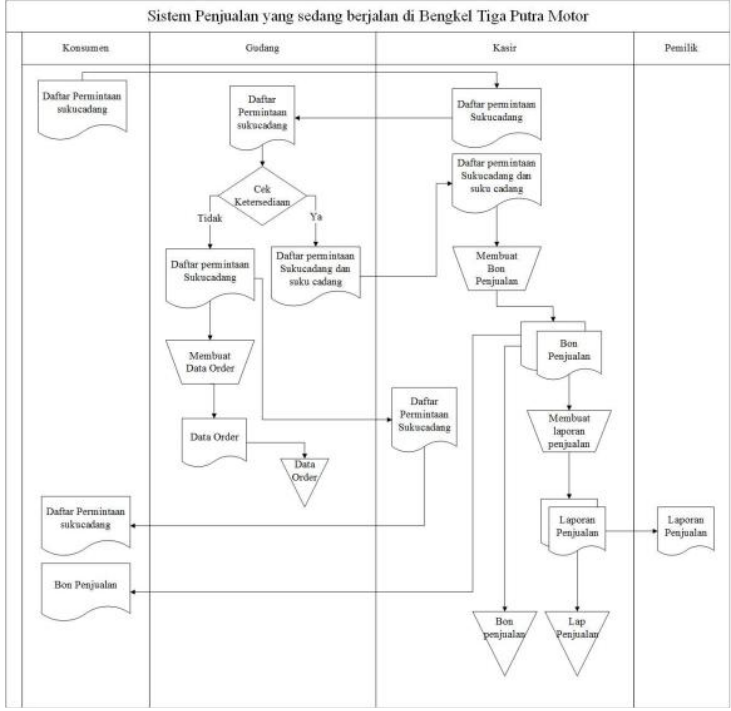

Gambar 2. Flow Map Penjualan yang sedang berjalan di Bengkel Tiga Putra Motor.

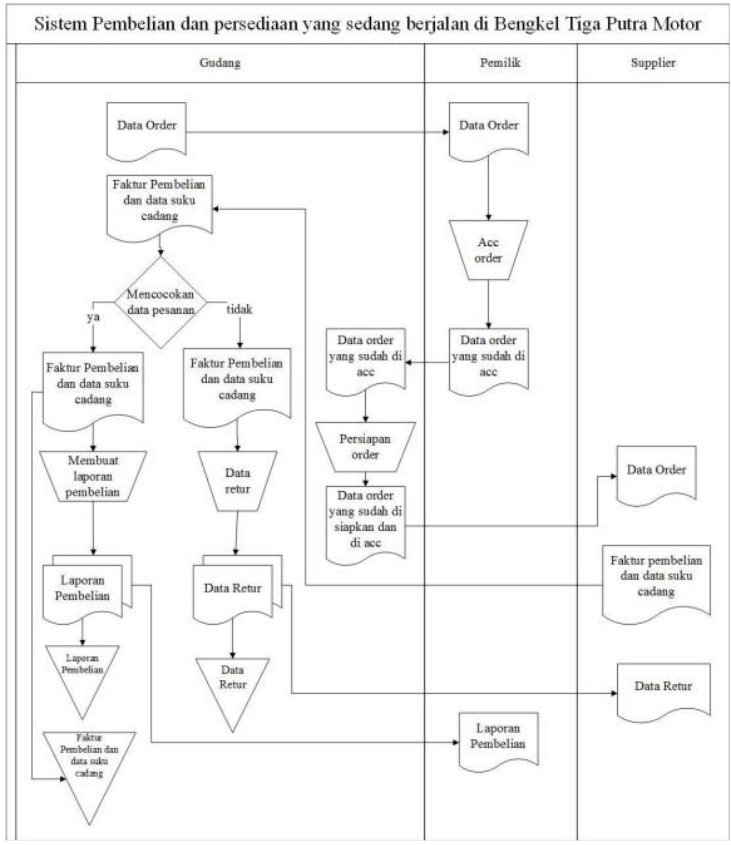

Gambar 3. Flow Map Pembelian dan Persediaan yang sedang berjalan di Bengkel

Tiga Putra Motor

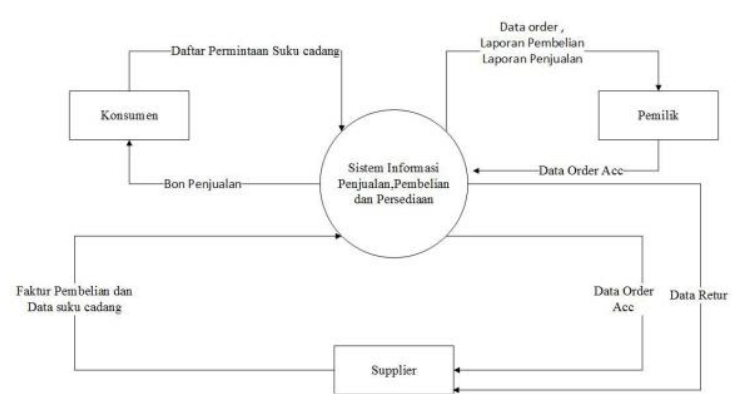

Gambar 4. Context Diagram Bengkel Tiga Putra Motor yang sedang berjalan 


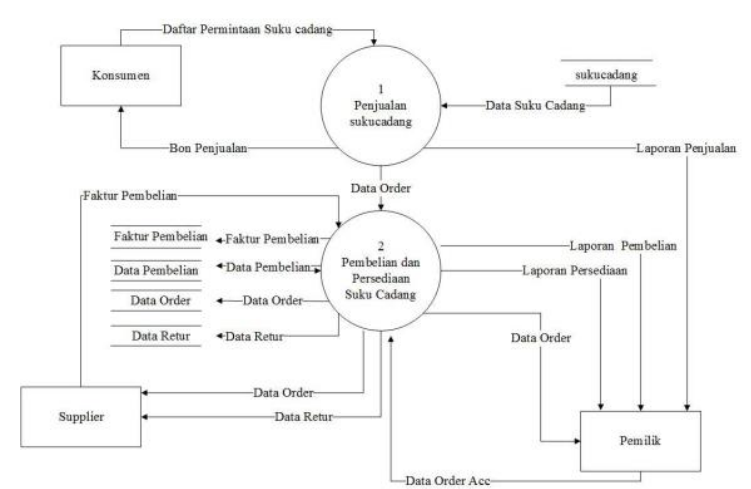

Gambar 5. DFD Level 1 yang sedang berjalan

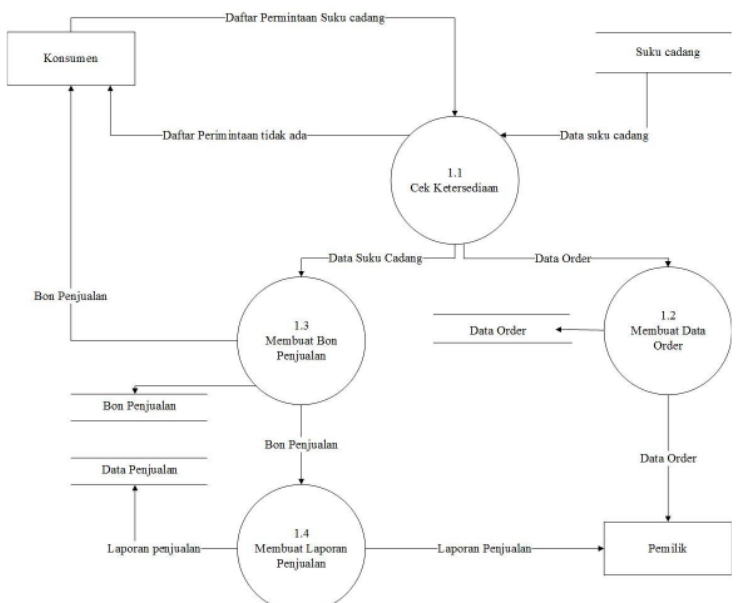

Gambar 6. DFD level 2 proses 1 yang sedang berjalan

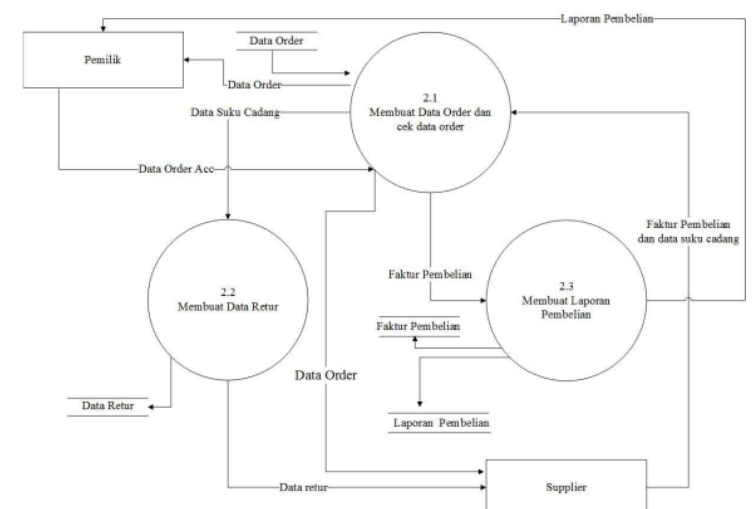

Gambar 7. DFD level 2 proses 2 yang sedang berjalan

\section{Evaluasi Prosedur yang Sedang Berjalan}

Setelah melewati beberapa tahapan analisa terhadap sistem informasi yang sedang berjalan di Bengkel Tiga Putra Motor maka dapat diketahui kelemahan-kelemahan yang terjadi pada sistem tersebut yang disajikan dalam Tabel berikut ini.
Tabel 1. Evaluasi Sistem yang sedang berjalan

\begin{tabular}{|c|c|c|c|c|c|}
\hline No. & Objek & Faktor & Masalah & Solusi & Bagian \\
\hline 1. & $\begin{array}{l}\text { Pengolahan } \\
\text { data } \\
\text { pembelian } \\
\text { dan Penjualan }\end{array}$ & \begin{tabular}{|l} 
Data \\
pembelian \\
dan \\
penjualan \\
disimpan \\
dalam bentuk \\
dokumen
\end{tabular} & $\begin{array}{ll}\text { Kesulitan } & \text { dalam } \\
\text { pencarian data ketika } \\
\text { dibutuhkan dan sulit } \\
\text { dalam pembuatan } \\
\text { laporannya saat data } \\
\text { hilang atau rusak }\end{array}$ & $\begin{array}{l}\text { Merancang } \\
\text { Aplikasi agar dapat } \\
\text { memberikan } \\
\text { informasi secara } \\
\text { luas dan memiliki } \\
\text { database yang } \\
\text { terintegrasi. }\end{array}$ & Kasir \\
\hline 2. & $\begin{array}{l}\text { Informasi data } \\
\text { stock suku } \\
\text { cadang dan } \\
\text { penjualan }\end{array}$ & $\begin{array}{l}\text { Hambatan } \\
\text { penyampaian } \\
\text { informasi } \\
\text { yang } \\
\text { berhubungan } \\
\text { dengan } \\
\text { penjualan } \\
\end{array}$ & $\begin{array}{l}\text { Sulit mengetahui stock } \\
\text { sukcadang yang sudah } \\
\text { terjual dan keadaan } \\
\text { kosong }\end{array}$ & $\begin{array}{l}\text { Dibangun aplikasi } \\
\text { yang dapat } \\
\text { mengetahui stock } \\
\text { suku cadang secara } \\
\text { cepat }\end{array}$ & Gudang \\
\hline 3. & $\begin{array}{l}\begin{array}{l}\text { Ketidak } \\
\text { akuratan data. }\end{array} \\
\end{array}$ & $\begin{array}{l}\text { Tidak adaya } \\
\text { sistem yang } \\
\text { berbasis } \\
\text { clientserver }\end{array}$ & $\begin{array}{l}\begin{array}{l}\text { Kesulitan dalam } \\
\text { pembuatan laporan }\end{array} \\
\end{array}$ & \begin{tabular}{|l|}
\multicolumn{2}{|l|}{ Dibangunnya } \\
sebuah aplikasi \\
yang berbasis \\
client-server
\end{tabular} & Kasir \\
\hline 4. & $\begin{array}{l}\text { Lama dalam } \\
\text { penerimaan } \\
\text { laporan. }\end{array}$ & $\begin{array}{l}\text { Laporan di } \\
\text { buat dalam } \\
\text { bentuk } \\
\text { dokumen } \\
\text { lembaran } \\
\text { kertas } \\
\end{array}$ & \begin{tabular}{|ll|}
\multicolumn{3}{|l|}{ Stok suku cadang tidak } \\
dapat di & kontrol \\
langsung &
\end{tabular} & 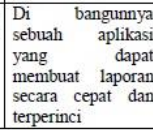 & Pemilik \\
\hline
\end{tabular}

\subsection{Perancangan Sistem}

Tahapan perancangan sistem adalah tahapan untuk memberikan gambaran mengenai sistem informasi pengolahan data penjualan, pembelian dan persediaan suku cadang yang akan diusulkan. Tahapan perancangan sistem merupakan penerjemah dari keperluan atau data yang telah dianalisis ke dalam bentuk yang mudah di mengerti oleh pemakai (user).

Perubahan sistem yang dilakukan pada pengolahan data pembelian adalah pembuatan data pesanan suku cadang secara terkomputerisasi, penginputan data pembelian. Adapun perancangan proses ini mencakup Flow map, Context Diagram, Data Flow Diagram, Relasi Tabel dalam Database dan ERD yang dapat menjelaskan aliran data yang diproses hingga menghasilkan informasi yang di inginkan.

\section{Flow Map Sistem yang Diusulkan}

Flow map memberikan gambaran tentang aliran atau perpindahan dokumen yang berjalan. Pembuatan flow map bertujuan untuk mengetahui lebih jelas aliran maupun perpindahan data-data yang ada, sehingga dapat diketahui kelebihan dan kekurangannya.

Gambar di berikut adalah Flow Map untuk sistem Penjualan, Pembelian dan Persediaan Suku Cadang yang di usulkan pada Bengkel Tiga Putra Motor yang dapat dilihat pada gambar 8 dan gambar 9 . 


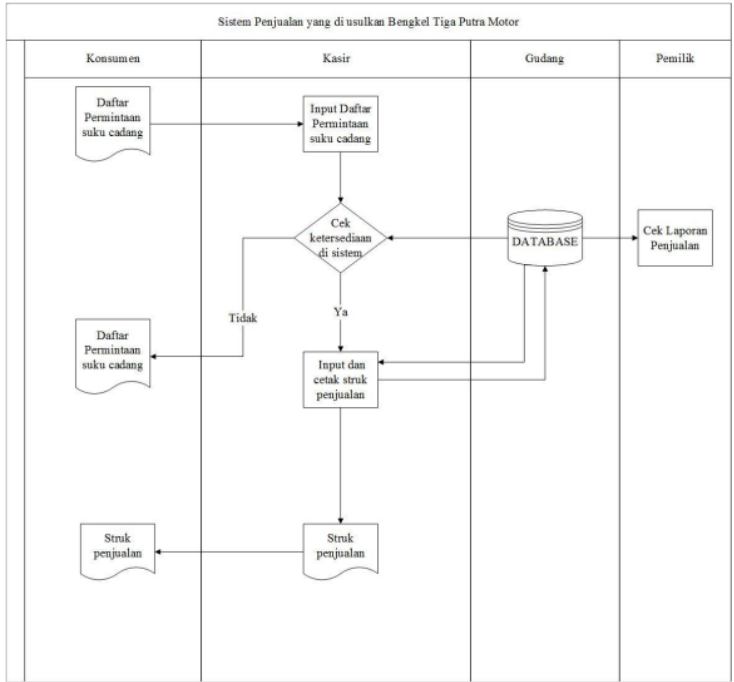

Gambar 8. Flow Map Sistem Penjualan yang Diusulkan

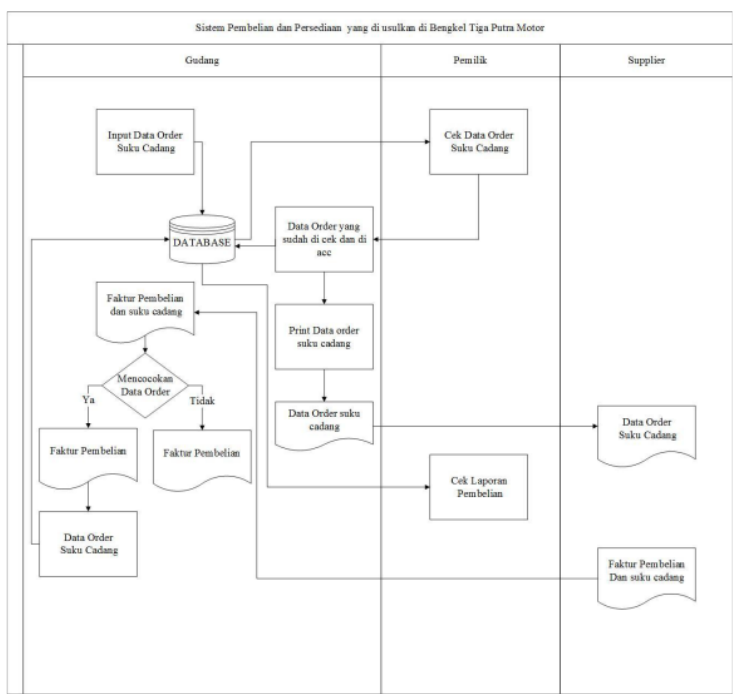

Gambar 9. Flow Map Sistem Pembelian dan Persediaan yang diusulkan

\section{Context Diagram Sistem yang Diususlkan}

Di bawah ini adalah Context Diagram sistem informasi pengolahan data penjualan ,pembelian dan persediaan suku cadang yang diusulkan pada bengkel Tiga Putra Motor.

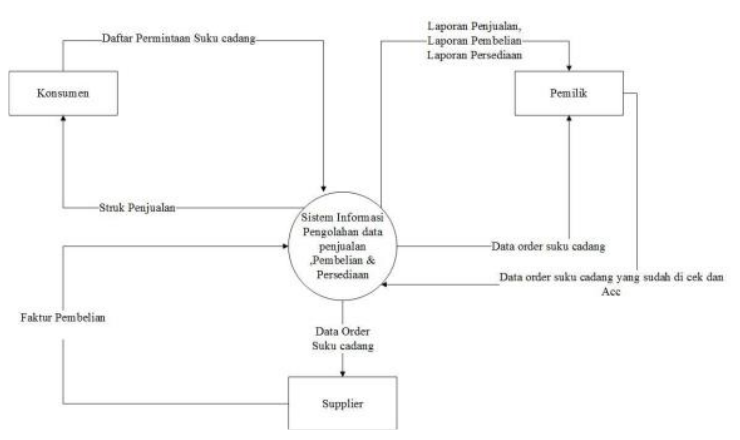

Gambar 10. Context Diagram Sistem Penjualan, Pembelian dan Persediaan yang diusulkan

\section{Data Flow Diagram (DFD)}

Data Flow Diagram atau dapat disebut Diagram aliran data merupakan teknik yang menjelaskan keadaan sebenarnya yang dibuat untuk menggambarkan dari mana asal dan kemana tujuan data yang keluar dari sistem, dimana data disimpan, proses apa yang mengahsilkan data tersebut dan interaksi antara data yang tersimpan dan proses yang di kenakan pada data tersebut.

Gambar di berikut adalah DFD untuk sistem Penjualan, Pembelian dan Persediaan Suku Cadang yang di usulkan pada Bengkel Tiga Putra Motor yang dapat dilihat pada gambar 11 sampai dengan gambar 13.

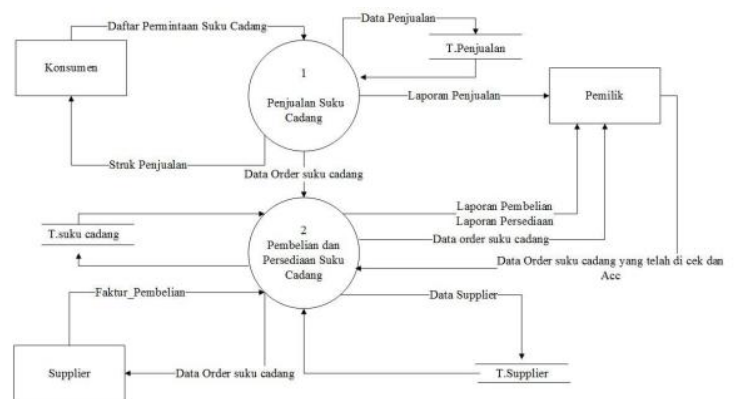

Gambar 11. DFD Level 1 yang diusulkan

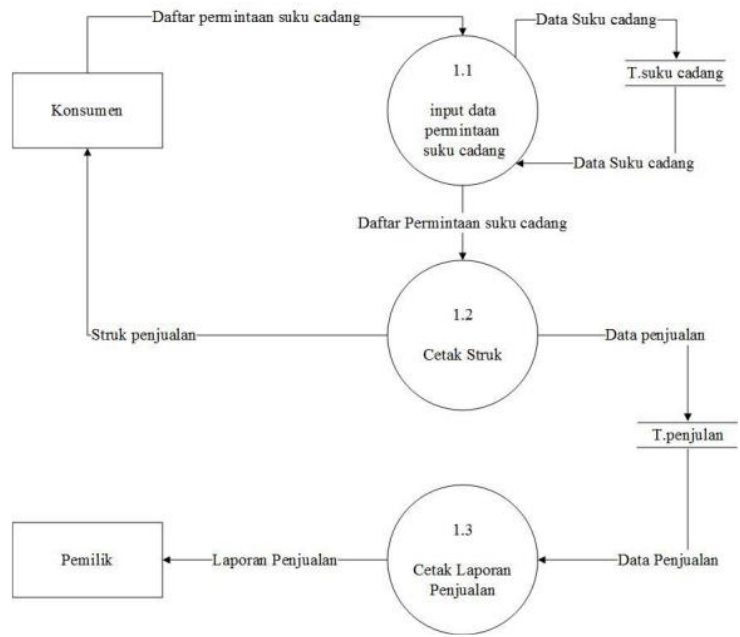

Gambar 12. DFD level 2 proses 1 yang di usulkan 


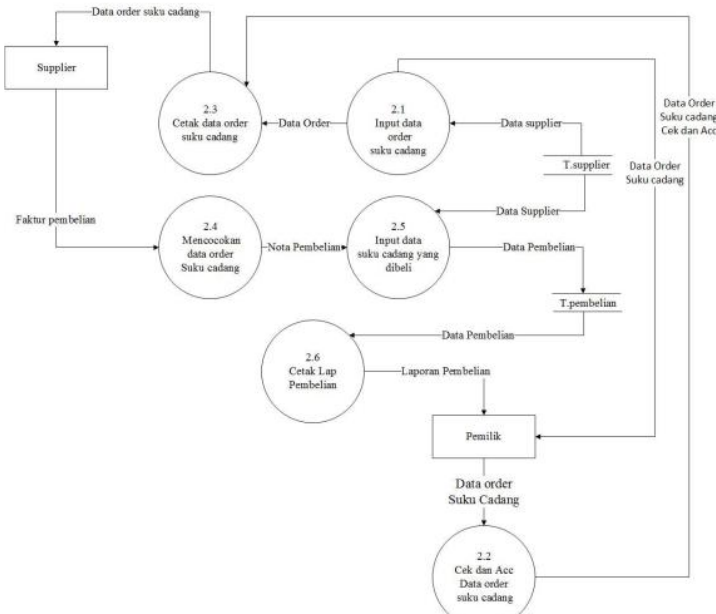

Gambar 13. DFD level 2 proses 2 yang di usulkan

\subsection{Perancangan Basis Data}

Perancangan basis data merupakan perancangan yang digunakan untuk pembuatan dan penyimpanan data ke dalam sistem terdiri dari beberapa file database. Pada perancangan basis data ini akan dibahas Relasi Tabel, Entity Relationship Diagram (ERD).

\section{Tabel Relasi}

Tabel relasi digunakan untuk mengelompokan data menjadi tabel-tabel yang menunjukan entitas dari relasi yang berfungsi untuk mengakses data sehingga database tersebut mudah di modifikasi.

Berikut ini di gambarkan relasi antar tabel :

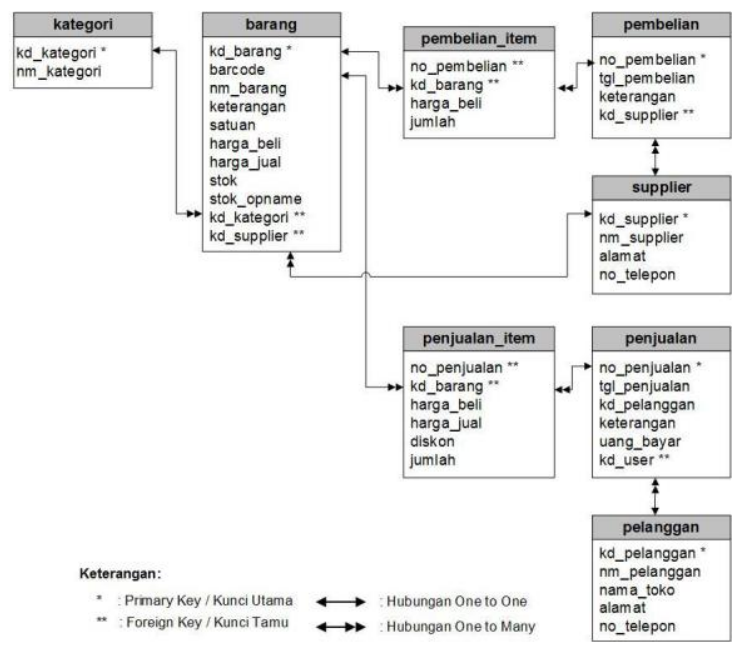

Gambar 14. Relasi Antar Tabel

\section{Entity Relationship Diagram (ERD)}

Entity Relationship Diagram (ERD) adalah bentuk bagan yang menggunakan relasi dan entitas suatu informasi.

Entitas relasi diagram dibuat dengan menggunakan presepsi yang terdiri dari sekumpulan objek yang ada dan dibedakan dari objek yang ada serta dibedakan dari objek lain.

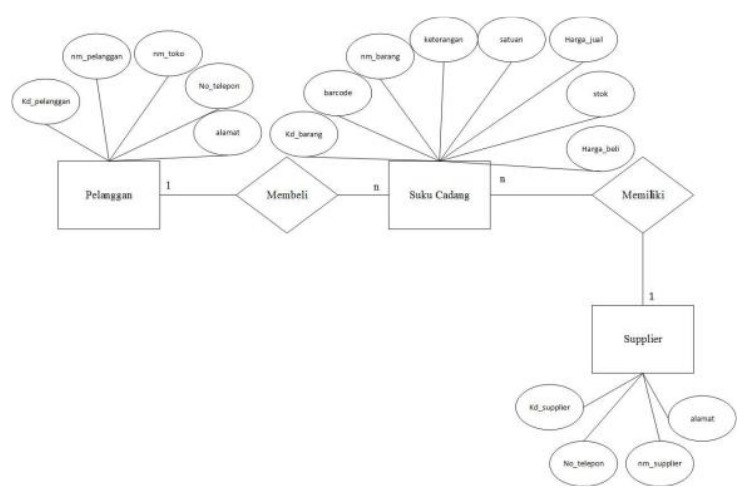

Gambar 15. Entity Relationship Diagram (ERD)

\subsection{Perancangan Antar Muka}

Pada bagian ini akan menjelaskan tentang perancangan antar muka aplikasi sistem informasi penjualan, pembelian dan persediaan suku cadang yang di bangun meliputi perancangan input dan perancangan output. Perancangan antar muka dapat dilihat pada gambar berikut.

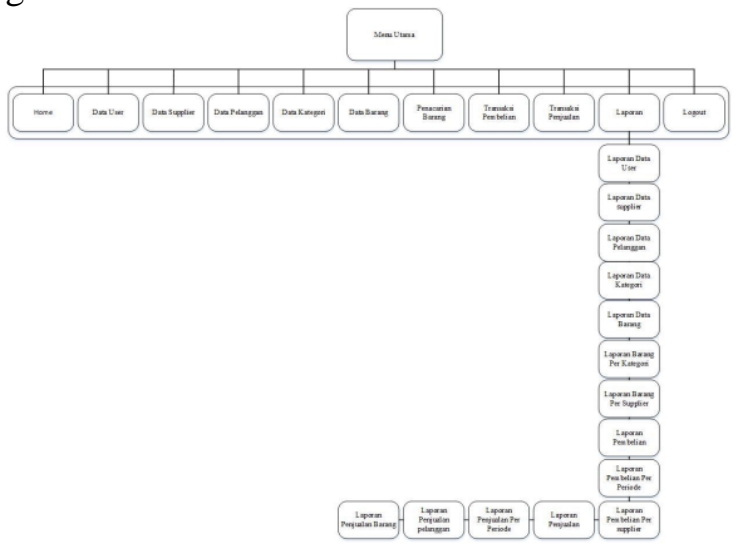

Gambar 16. Perancangan Struktur Menu 


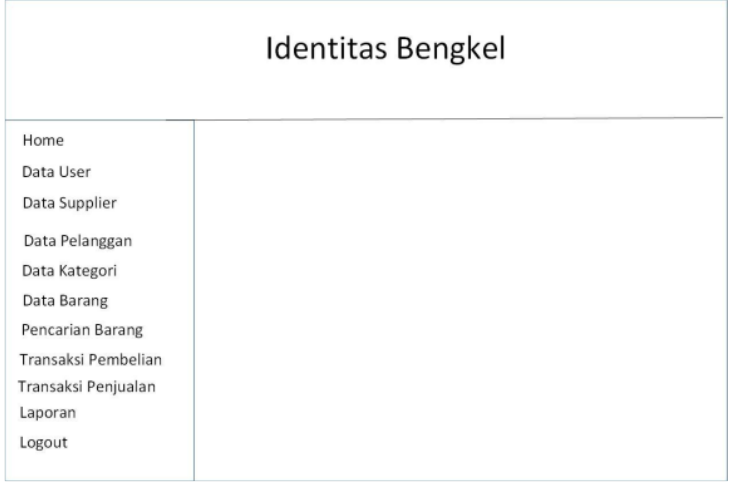

Gambar 17. Perancangan Menu Utama

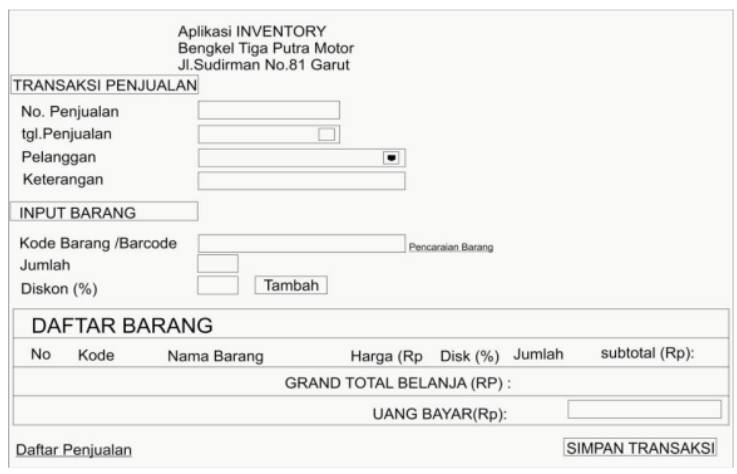

Gambar 18. Perancangan Form Penjualan

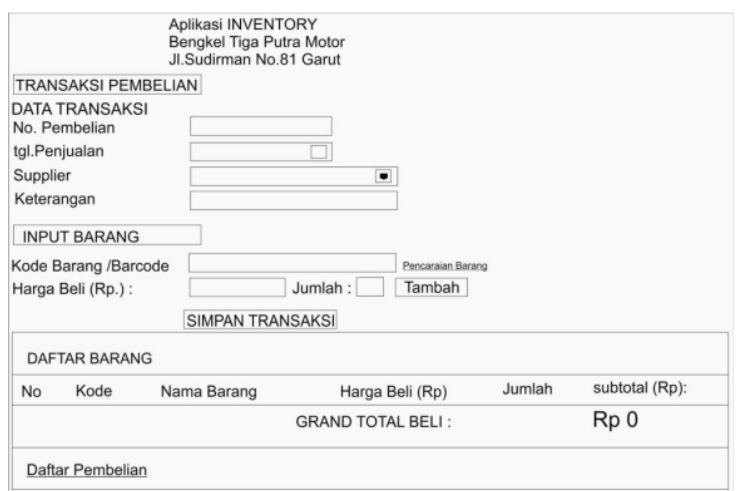

Gambar 19. Perancangan Form Pembelian

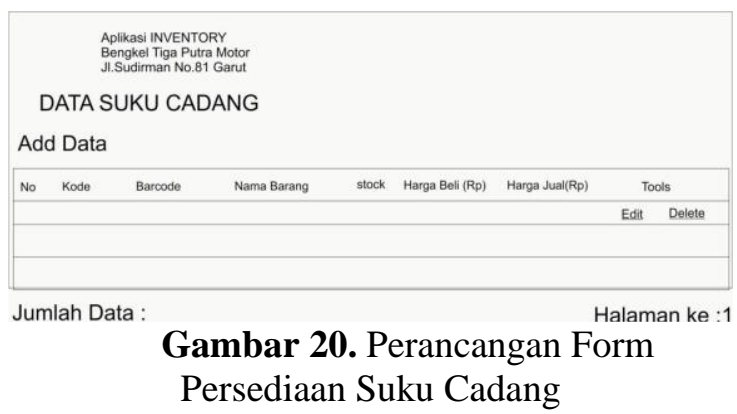

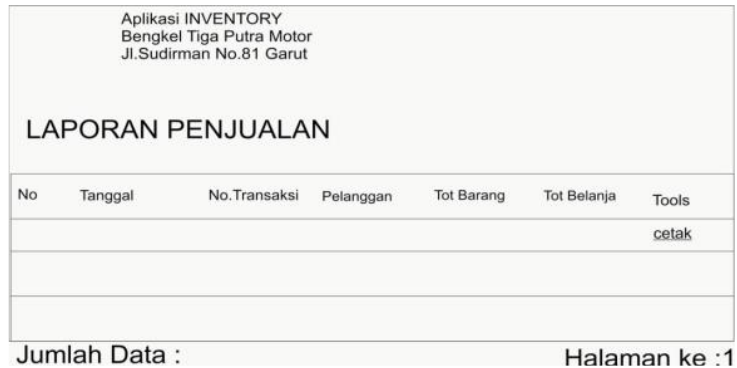

Gambar 21. Perancangan Form Laporan Penjualan

\subsection{Perancangan Arsitektur Jaringan}

Adapun kebtuhan untuk mendukung program ini adalah sebagai berikut :

1. Tipe jaringan yang di gunakan adalah WLAN (Wireless Local Area Network), dengan model konfigurasi dimana satu komputer bertindak sebagai server, dan yang lainnya sebagai client yang mengakses file dalam server.

2. Media transmisi jaringan nirkabel atau di kenal dengan nama Wireless, merupakan salah satu media transmisi yang menggunakan gelombang radio sebagai media transmisinya.

3. Topologi yang digunakan adalah topologi star(Bintang), karena tingkat kesulitannya lebih sederhana dan kinerjanya yang optimal karena lintas dari terminal ke server yang pendek.

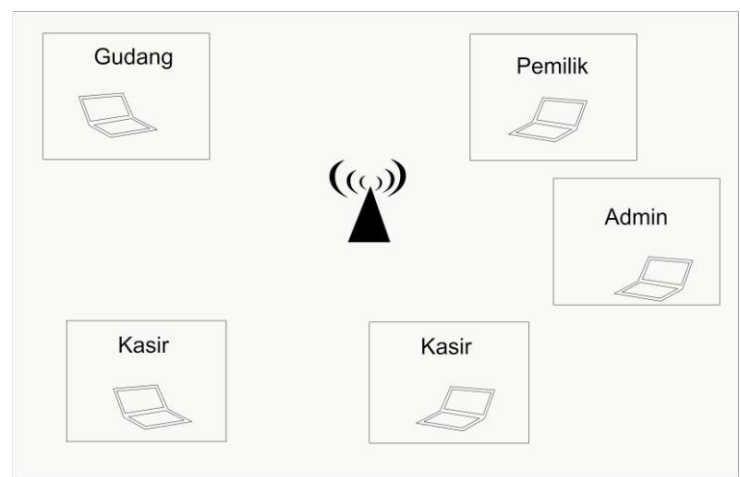

Gambar 22. Desain Infrastruktur Jaringan

\subsection{Implementasi Program}

Adapun implementasi dari perancangan antarmuka aplikasi yang telah dirancang dapat dilihat sebagai berikut : 


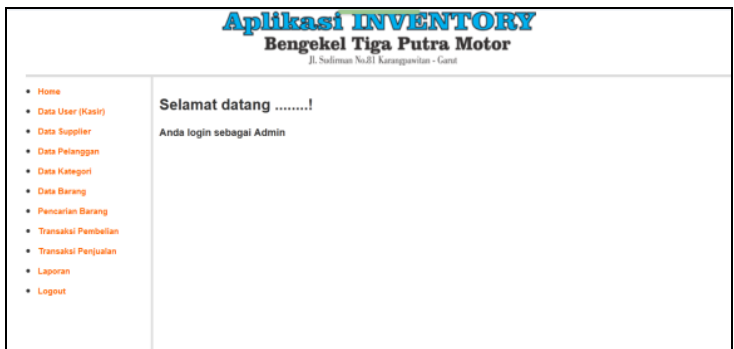

Gambar 23. Tampilan Menu Utama

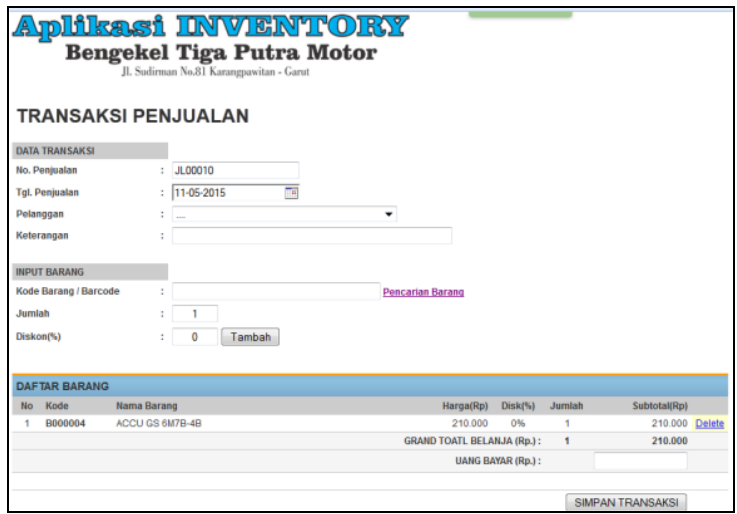

Gambar 24. Form Penjualan

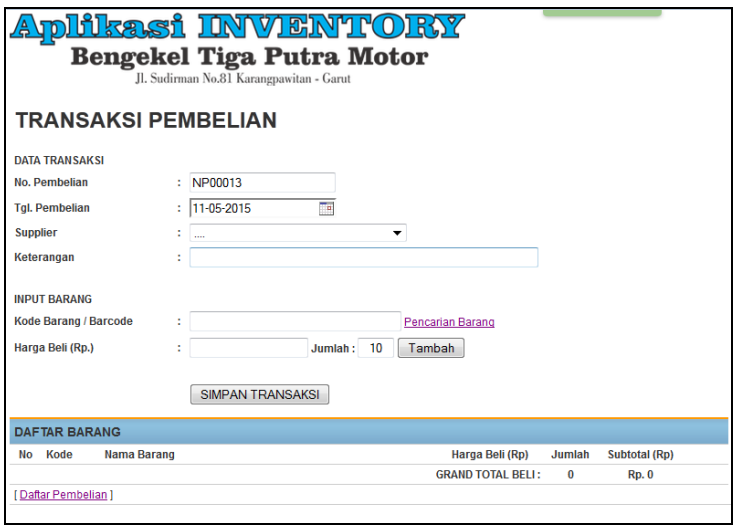

Gambar 25. Form Pembelian

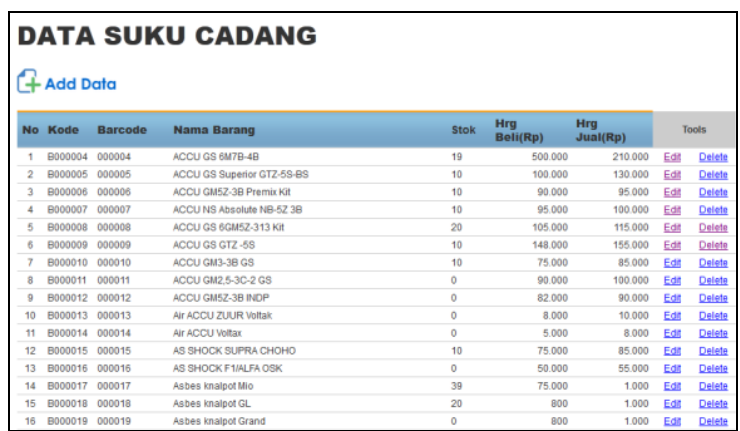

Gambar 26. Persediaan Suku Cadang

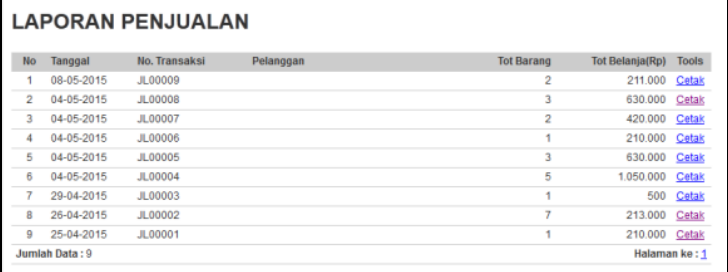

Gambar 27. Laporan Penjualan

\section{KESIMPULAN}

Berdasarkan hasil analisis, perancangan yang telah dilakukan dalam pembuatan aplikasi sistem informasi penjualan, Pembelian dan persediaan suku cadang pada Bengkel Tiga Putra Motor ini maka dapat diambil beberapa kesimpulan sebagai berikut:

1. Aplikasi Sistem Informasi Penjualan, Pembelian dan Persediaan Suku Cadang dari hasil penelitian ini dapat memberi kemudahan akses informasi dan proses transaksi penjualan bagi kasir untuk melayani dan mendapatkan informasi suku cadang yang dibutuhkan oleh konsumen.

2. Proses pengontrolan stok suku cadang menjadi lebih efektif dan efisien sehingga memberi kemudahan mendapatkan informasi stok yang ada dan kontrol keluar masuknya suku cadang.

3. Pengolahan data menjadi lebih baik karena disimpan dalam suatu basis data yang terintegrasi sehingga pembuatan laporan lebih akurat dan cepat.

\section{REFERENSI}

[1] Al-Bahra. 2005. Analisis dan Desain Sistem Informasi. Graha Ilmu. Yogyakarta.

[2] Jogiyanto, HM. 2005. Analisis Dan Desain Sistem Informasi : Pendekatan Terstruktur, Teori Dan Praktik Aplikasi Bisnis. Andi. Yogyakarta.

[3] Kotle. Philip. 2006. Manajemen Pemasaran Edisi 11. PT. Indeks. Jakarta.

[4] Mulyadi. 2001. Sistem Akuntansi. Salemba Empat. Jakarta

[5] Suhayati, Ely. dan Anggadini, Sri Dewi. 2009. Akuntansi Keuangan. Graha Ilmu. Yogyakarta

[6] Pressman, Roger S. 2002. Rekayasa 
Perangkat Lunak. Andi. Yogyakarta.

[7] Sutabri, Tata. 2012. Konsep Sistem Informasi. Andi offset Yogyakarta .

[8] Irawan, Budhi. 2005. Jaringan Komputer. Graha Ilmu. Yogyakarta.

[9] Kristanto, Andi. 2008. Perancangan
Sistem Informasi dan Aplikasinya. Gava Media. Yogyakarta.

[10] Simarmata, Janner. 2007. Perancangan Basis Data. Andi. Yogyakarta. 